\title{
Spatial structure and inbreeding depression in slickspot peppergrass, Lepidium papilliferum (Brassicaceae)
}

\author{
Stephanie A. Billinge and lan C. Robertson
}

\begin{abstract}
In plants with limited pollen and seed dispersal, populations are often spatially structured such that neighboring individuals are more closely related to one another than to distant individuals. Mating among close relatives, including selfing, may lead to a reduction in reproductive performance through the effects of prezygotic mating barriers and inbreeding depression. Studying 11 populations of slickspot peppergrass, Lepidium papilliferum (L.F. Hend.) A. Nels. and J.F. Macbr (Brassicaceae), a rare mustard endemic to southwestern Idaho, we investigated whether small populations (16746 flowering individuals) exhibit spatial structure as previously reported for large populations ( $>3000$ flowering individuals). Through hand-pollination experiments we found that percent fruit set increased with increasing distance between parents up to a distance of $3 \mathrm{~m}$, and declined slightly but nonsignificantly at greater outcrossing distances. Self-pollinated plants produced little or no fruit. Germination of seeds from the hand-pollination experiment revealed signs of inbreeding depression in the offspring. Specifically, leaf length of developing seedlings increased significantly as a function of outcrossing distance. Total leaf number showed a similar, yet statistically nonsignificant, response to outcrossing distance. Overall, our experiments reveal spatial structuring and suggest the occurrence of inbreeding depression in small populations of L. papilliferum.
\end{abstract}

Key words: inbreeding depression, outcrossing, pollination, spatial structure.

Résumé : Chez les plantes ayant des dispersions de pollens et de graines limitées, on retrouve souvent des populations structurées de telle façon que les individus voisins se côtoient plus étroitement que les individus distants. Les croisements entre individus étroitement apparentés, incluant l'autofécondation, peuvent conduire à une réduction des performances de reproduction par les effets de barrières de croisement pré-zygotiques et la dépression d'autofécondation. En étudiant 11 populations de la lépidie papillée, Lepidium papilliferum (L.F. Hend.) A. Nels et J.F. Macbr (Brassicaceae), une moutarde endémique rare du sud-ouest de l'Idaho, les auteurs ont cherché à savoir si les petites populations (16 à 746 individus fleurissants) montrent une structure de population comme précédemment rapportée pour de grandes populations ( $>3000$ individus florissants). À l'aide d'expériences de pollinisation, ils ont constaté que le pourcentage de mise à fruit augmente avec une augmentation de la distance entre les parents jusqu'à $3 \mathrm{~m}$, et diminue légèrement, mais de façon non significative pour des distances de croisements externes plus grandes. Les plantes autofécondées produisent peu ou pas de fruits. La germination des graines provenant de pollinisations manuelles montre des signes de dépression d'autofécondation chez les descendants. Spécifiquement, la longueur des feuilles des plantules en développement augmente significativement en fonction de l'augmentation de la distance des autofécondations. Le nombre total de feuilles montre une réaction similaire en fonction de la distance d'autofécondation, bien que non significatif. En général, les auteurs observent une structuration spatiale et suggèrent qu'une dépression d'autofécondation survient dans les petites populations du L. papilliferum.

Mots-clés : dépression d'autofécondation, hétérocroisement, pollinisation, structure spatiale.

[Traduit par la Rédaction]

\section{Introduction}

The extent to which organisms outcross can have a profound effect on their reproductive success and fitness. Mating among close relatives, including selfing, may lead to a reduction in offspring number because of shared selfincompatibility alleles in the parents, or a reduction in offspring fitness because of an increase in homozygosity and

Received 26 November 2007. Published on the NRC Research Press Web site at botany.nrc.ca on 29 August 2008.

S.A. Billinge and I.C. Robertson. ${ }^{1}$ Department of Biological Sciences, Boise State University, 1910 University Drive, Boise, ID 83725, USA.

${ }^{1}$ Corresponding author (e-mail: iroberts@boisestate.edu). expression of deleterious alleles (Waser 1993). The latter effect, known as inbreeding depression (Charlesworth and Charlesworth 1987), is often reflected in plants by a reduction in seed production and germination, decreased growth rates, increased offspring mortality, and reduced offspring fertility (Charlesworth and Charlesworth 1987; Sobrevila 1988; Waser and Price 1989; Oostermeijer et al. 1995; Byers 1998).

In spatially structured plant populations, neighboring individuals often are more closely related to one another than to distant individuals because of limited pollen flow and seed dispersal. As a result, matings between neighbours exhibit decreased fitness relative to more distant matings (Levin 1984; Waser and Price 1989, 1994; Waser 1993; Oostermeijer et al. 1995; Byers 1998). However, small pop- 
Table 1. Mixed Model ANOVA results for percent fruit set, seed mass, and percent germination.

\begin{tabular}{|c|c|c|c|c|c|c|}
\hline \multirow[b]{2}{*}{ Random effects } & \multicolumn{2}{|c|}{ Percent fruit set } & \multicolumn{2}{|c|}{ Seed mass } & \multicolumn{2}{|c|}{ Percent germination } \\
\hline & Estimate & SE & Estimate & SE & Estimate & SE \\
\hline Site & 36.9 & 46.6 & 0.06 & 0.03 & 148.8 & 126.7 \\
\hline Site $\times$ treatment & 18.0 & 68.2 & 0.001 & 0.001 & & \\
\hline Residual & 688.8 & 101.3 & 0.013 & 0.001 & 769.9 & 131.9 \\
\hline Fixed effects & df & $F$ & df & $F$ & df & $F$ \\
\hline Treatment & $5,25.7$ & $19.7^{a}$ & $4,13.9$ & $2.39^{b}$ & $4,70.2$ & $1.47^{c}$ \\
\hline
\end{tabular}

ulations are generally expected to exhibit less spatial structure than large populations because of reduced genetic variability and higher levels of inbreeding, particularly if the populations are genetically isolated (Ellstrand and Elam 1993). Decreases in fitness caused by inbreeding are of particular concern for rare species, which are often threatened with local extinction because of demographic processes associated with small population size (Ellstrand and Elam 1993; Lande 1995; Byers 1998). Thus, the relationship between outcrossing distance and offspring fitness may have important consequences for rare species because any decrease in offspring fitness can threaten the species' longterm viability (Ellstrand and Elam 1993; Byers 1998).

Here we use various cross pollination distances to examine spatial structure and inbreeding depression in slickspot peppergrass, Lepidium papilliferum (L.F. Hend.) A. Nels. and J.F. Macbr., a rare mustard endemic to sagebrush steppe habitat in southwest Idaho. Within sagebrush-steppe habitat, L. papilliferum is restricted to microsites known as slick spots - small depressions of soil characterized by their high levels of clay and salt, as well as by subsurface water retention that is higher than that of surrounding areas (Quinney 1998). Currently only 60-70 sites ( (sites = populations for the purposes of our study) are known to contain L. papilliferum, many of which support no more than a few hundred individuals (Colket 2005). Declines in the plant's numbers, including the extirpation of 21 populations since 1892 , have been attributed to the fragmentation, destruction, and overall degradation of sagebrush-steppe habitat throughout the plant's range (Moseley 1994).

Lepidium papilliferum is a monocarpic plant that relies primarily on outcrossed pollination mediated by insects (Robertson and Klemash 2003), although it has a limited ability to self pollinate (Billinge 2006; Stillman 2006). Fruits produced from fertilized flowers reach full size approximately 2 weeks after pollination (Robertson and Klemash 2003). Each fruit typically bears two seeds that drop to the ground when the fruit dehisces in midsummer. Seeds that drop to the ground can remain viable within the seed bank for up to 11 years (Meyer et al. 2005).

Studying three relatively large populations of L. papilliferum (>3000 flowering individuals), Robertson and Ulappa (2004) analyzed fruit set as a function of outcrossing distance and concluded that those populations were spatially structured. Self pollination resulted in only $12 \%$ fruit set, whereas fruit set jumped significantly to $45 \%$ for pollination distances of 75-100 m. Although these results shed light on the spatial structure of large L. papilliferum
Fig. 1. Box plot chart showing fruit production as a function of outcrossing treatment. The boxes represent the median, and 25 th and 75 th percentiles, whereas whiskers represent the maximum and minimum values. Different letters above bars indicate significant differences among treatments. An asterisk indicates that the values are not significantly different from zero. Numbers below labels indicate sample size. $\mathrm{C}$, control; $\mathrm{S}$, self-pollination; NN, nearestneighbor pollination; AS, across-slick-spot pollination; Bss, between-slick-spot pollination; Bsite, between-site pollination.

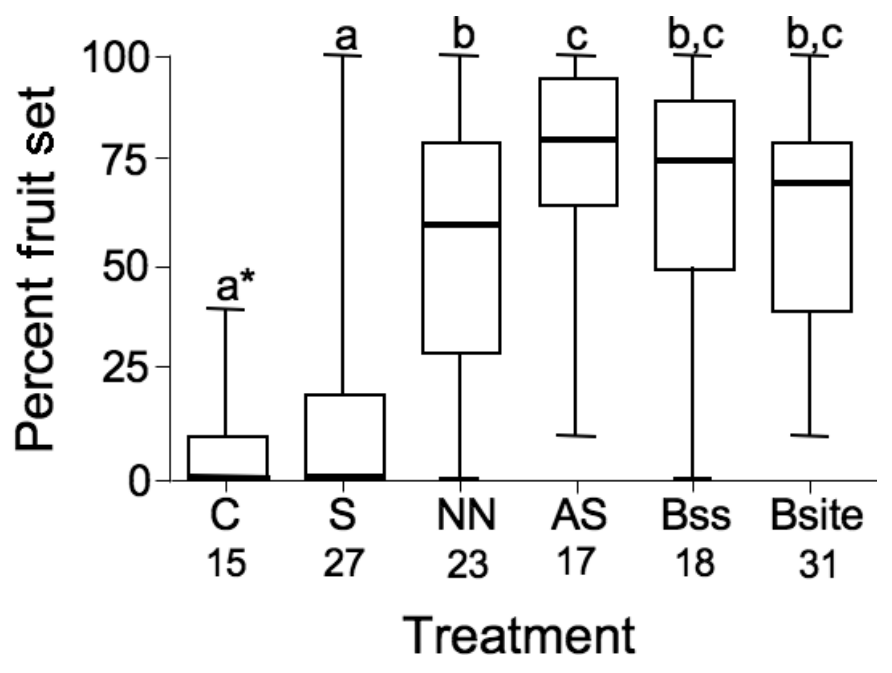

populations, most populations of this rare species are substantially smaller and, in some cases, more isolated than those used by Robertson and Ulappa. Thus, the first goal of our study was to determine whether small $L$. papilliferum populations exhibit spatial structure similar to that found in large populations. Our second goal was to determine whether L. papilliferum exhibits inbreeding depression. Although fruit production, the only measure of reproduction used by Robertson and Ulappa (2004), may be an important component of a plant's reproductive success, offspring from crosses that yield similar amounts of fruit may differ in other ways that affect parental fitness. Consideration of seed mass, germination success, and seedling growth can contribute to a more comprehensive picture of reproductive performance (Waser and Price 1989; Waser 1993; Oostermeijer et al. 1995; Byers 1998). Therefore, in addition to measuring percent fruit set as a function of outcrossing distance, we collected seeds from the crosses, germinated them, and measured seedling growth and development. 


\section{Materials and methods}

Study sites

We conducted our study in 2005 and 2006 using 11 L. papilliferum populations from across the plant's range. Ten of the populations supported $<750$ flowering individuals (mean $=204$, range 16-746) and were considered small. The other population had 3602 flowering individuals and was considered large. Only one large population was included in the study because two previous studies had established that populations with over 3000 flowering plants were spatially structured (Robertson 2004; Robertson and Ulappa 2004). The large population was included for comparison with the previous studies, and as a control for year in our comparisons between large and small populations. Germination and growth studies were conducted in greenhouses at Boise State University.

\section{Spatial structure and inbreeding depression}

We conducted an experiment to determine whether small populations of $L$. papilliferum are structured in a manner similar to that reported for large populations. At each site we selected up to five slick spots containing L. papilliferum (smaller populations often had fewer than five slick spots). In each slick spot we selected up to six plants of similar size and showing unopened flower buds. To prevent pollination by insects we placed cylindrical insect-proof cages (constructed from $1 \mathrm{~cm}^{2}$ hardware cloth covered with fine $0.25 \mathrm{~mm}^{2}$ white mesh) over the plants before they flowered. This cage design does not restrict plant growth or fruit production in L. papilliferum (Robertson and Klemash 2003).

In slick spots where six plants were caged, we randomly assigned each plant either to the control ( $C$, no manipulation) or to one of five hand-pollination treatments: selfing (S), nearest neighbor (NN, cross pollination with plant < $1 \mathrm{~m}$ away), across slick spot (AS, cross pollination with plant approximately $3 \mathrm{~m}$ away but within the same slick spot), between slick spot (Bss, cross pollination with a plant 20-50 m away), and between site (Bsite, cross pollination with a plant from another population $2.5-7 \mathrm{~km}$ away), with none of the treatments being repeated within a slick spot. For each hand pollination treatment we cut an inflorescence from the pollen donor. We then contacted the anthers of one donor flower to the stigma of one recipient flower on the treatment plant. Ten flowers on an inflorescence of the recipient plant were pollinated in this manner. We used each pollen donor flower only once to pollinate a treatment flower. We then tagged the inflorescence of the recipient plant with a string for identification later in the summer.

When fewer than six plants per slick spot were available, as was the case for some of the smaller populations, we assigned treatments in the following order of priority: $S$ and Bsite, NN, AS, C, and Bss. Self and Bsite treatments were carried out at all sites to quantify selfing ability and to verify the plants' ability to produce successful offspring using pollen from distant populations. The intermediate distance treatments (NN, AS, and Bss) were added to each slick spot as plants were available to examine the spatial structure within populations.

Two weeks after hand pollination we counted the number of fruit produced on an inflorescence, and we measured the width of each fruit in situ using digital calipers. Previous work revealed that fruits less than $1.5 \mathrm{~mm}$ in width do not contain seeds (I.C. Robertson, unpublished data, 2005). Therefore, only fruits $1.5 \mathrm{~mm}$ or wider were scored as successful. In mid-July, when fruits were ready to dehisce, we collected seeds from the crosses and stored them in paper envelopes (one per plant) at room temperature. We weighed the seeds on a Cahn C-35 microbalance, and then assigned each seed a number unrelated to its treatment so that germination and growth measurements would not be subject to experimenter bias. We then stored the seeds at room temperature and without light for 3 months. To promote germination we scarified seeds by rubbing them gently between two sheets of 320 grit sandpaper. We then imbibed the seeds with deionized water for $24 \mathrm{~h}$ on filter paper in Petri dishes, and placed them in cold stratification at $4{ }^{\circ} \mathrm{C}$ for 8 weeks with no light. Afterward, we planted the seeds $2-4 \mathrm{~mm}$ deep in peat-based soil (Sunshine Professional Growing Mix No. 3, Bellevue, Wash.) mixed with a micronutrient fertilizer (Whitney Farms Life Link Smart Start Transplanting Fertilizer [2-4-2], Scotts Miracle-Gro Co., Marysville, Ohio), and placed them in a greenhouse maintained at $21{ }^{\circ} \mathrm{C}$ during the day and $10{ }^{\circ} \mathrm{C}$ at night, with a $14 \mathrm{~h}$ daylight photoperiod. Following germination, we used digital calipers to record the length of a specific leaf from each seedling every three days for a total of $30 \mathrm{~d}$. At each time interval we also recorded the total number of leaves on each plant.

\section{Statistical analyses}

We used SAS 9.1.3 (SAS Institute Inc. 2003) for all analyses. For each of the crosses performed we used linear mixed models to analyze percent fruit set, seed mass, and percent germination. These models accounted for the variation within sites, assuming that populations are statistically independent of each other. Owing to the limited availability of plants at some sites, and because some plants died during the course of the experiment, the data were not balanced with respect to treatments and sites. The fixed effect in all models was treatment (i.e., outcrossing distance). The random effects included site, slick spot nested within site, and (or) site $\times$ treatment interaction, depending on the outcome; not all random effects could be fit to all outcomes as a result of treatment balance across sites, or because of a lack of variation caused by the effect. Therefore, we used Satterthwaite's adjustment to degrees of freedom for each of the analyses (Milliken and Johnson 1992). To assess the fit of the model, plots of the residuals were examined for normality and homogeneity of variance. Without an overall $F$ test for the site $\times$ treatment interactions, we examined whether treatments differed between the large site and the smaller sites by comparing estimated mean differences between the large site and the mean of the small sites. We estimated these differences as a specific linear contrast of the model coefficients, and tested it against null using an approximate $t$ tests (SAS Institute Inc. 2003).

We fit a random coefficients model to leaf length and the total number of leaves produced by a plant, which effectively fits a trend to the plants' growth and accounts for repeated observations on each plant. Data for this analysis were natural-log transformed ( 0.5 was added to each meas- 
Table 2. Mixed model estimates of percent fruit set with respect to treatment for the large site and the average of the small sites.

\begin{tabular}{lll}
\hline Treatment & Estimate for large population & Estimate for combined small populations \\
\hline Control (C) & $5.9(-12.5,24.2)$ & $9.0(-4.8,22.9)$ \\
Self (S) & $13.1(-5.2,31.5)$ & $19.3(8.9,29.8)$ \\
Nearest neighbour (NN) & $48.1(16.5,79.7)$ & $54.5(43.2,65.9)$ \\
Across slick spot (AS) & $72.7(55.6,89.8)$ & $77.2(63.8,90.5)$ \\
Between slick spot (BSS) & $65.0(46.2,83.7)$ & $68.9(56.2,81.6)$ \\
Between site (Bsite) & $55.0(35.6,74.3)$ & $77.5(62.3,92.7)$ \\
\hline
\end{tabular}

Note: Values are means with $95 \%$ confidence limits in parentheses. No significant differences in estimates were found between the large site and small sites (all $P>0.30$ ).

ure to prevent errors when transforming values of zero). The fixed effects were study day and treatment (the interaction between them was assessed by AICc and subsequently dropped (Burnham and Anderson 2002)). Total leaf number was modeled by Poisson regression, accounting for repeated measures on individual plants. No additional covariance terms were included because of nonconvergence. Again the fixed effects were treatment and day. We assessed the fit of the model using residual plots for normality and homogeneity of variance.

\section{Results}

Table 1 provides the mixed-model analysis of variance results for percent fruit set, seed mass, and percent germination. There were significant differences among treatments for percent fruit set only. Referring to Fig. 1, median percent fruit set increased with increasing distance between parents up to the across slick spot treatment, and declined slightly at distances greater than the across slick spot treatment. As expected, the control and selfing treatments were not different from each other, but were significantly lower than the other four treatments. The between slick-spot and between site treatments were not significantly different from each other, nor were they different from the across slick-spot or nearest neighbor treatment; however the latter two were significantly different from each other. Table 2 gives the model-estimated percent fruit set by treatment for the large site $(\mathrm{KB})$ and the average of the small sites. Because none of the contrasts between large and small sites were statistically significant (all $P>0.30$ ), we did not further adjust the $P$ values for multiple comparisons.

Although we found no statistically significant effect of treatment on seed mass or percent seed germination (Table 1), the pattern of percent germination with respect to treatment was similar to that found for percent fruit set (Fig. 2). No pattern was evident between seed mass and treatment. However, seed mass correlated positively with percent germination and offspring leaf length (Pearson correlation coefficients: percent germination, $r=0.38, P<$ 0.001 ; leaf length, $r=0.37, P=0.01)$.

The analysis of variance results for the model of leaf length are shown in Table 3. Leaf length in developing seedlings was significantly different across treatments $\left(F_{[4,734]}=\right.$ 15.6, $P<0.0001)$ and over time $\left(F_{[1,67.5]}=219.0, P<\right.$ $0.0001)$. As outcrossing distance between parents increased, mean leaf length in offspring increased (Fig. 3).

The total number of leaves on developing plants increased significantly over time (GEE score $\chi^{2}=75.51$, df $=1, P<$
Fig. 2. Box plot chart showing percent germination as a function of treatment. The boxes represent the median, and 25th and 75th percentiles, whereas whiskers represent the maximum and minimum values. Different letters above bars indicate significant differences among treatments. Numbers below labels indicate sample size. See Fig. 1 caption for treatment acronyms.

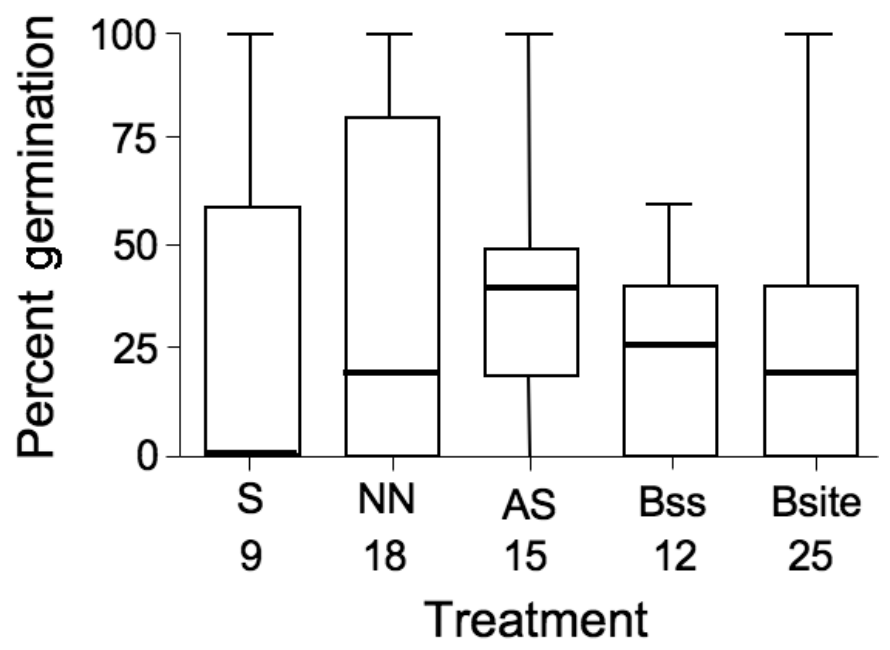

0.0001). Although there was no significant effect of treatment on leaf number (GEE score $\chi^{2}=8.62$, df $=4, P=$ 0.07 ), the general pattern for the effect of outcrossing distance on plant growth held to the extent that plants from the selfing cross had the fewest leaves, whereas plants from the between-site cross had the most leaves (Fig. 4).

\section{Discussion}

Percent fruit set in L. papilliferum increased as a function of outcrossing distance up to the across slick spot treatment (i.e., $3 \mathrm{~m}$ outcrossing distance), and then declined slightly, but nonsignificantly, over larger distances. This pattern of percent fruit set as a function of outcrossing distance is similar to that reported by Robertson (2004) and Robertson and Ulappa (2004), although in those studies outcrossing distances between 1 and $75 \mathrm{~m}$ were not considered. The rapid increase in percent fruit set we found over relatively short outcrossing distances suggests either that genetic relatedness among individuals declines sharply as a function of distance, or that L. papilliferum, while intolerant of high levels of inbreeding (as experienced in selfing and nearest neighbor pollination treatments), is tolerant of low levels of inbreeding. Either way, because self-pollinated individuals had low reproductive output in all populations studied, our 
Table 3. Analysis of variance results for models of leaf length.

\begin{tabular}{llll}
\hline Random effects & Estimate & SE \\
\hline Site & 0.0834 & 0.05 \\
Variance within plant, at a given day & 0.0001 & 0.0002 \\
Variance within plant, between days & 0.0004 & 0.0002 \\
Residual & 0.0313 & 0.002 \\
\hline Fixed effects & df & $F$ & $P$ \\
\hline Day & $1,67.5$ & 219.0 & $<0.0001$ \\
Treatment (outcrossing distance) & 4,734 & 15.6 & $<0.0001$ \\
\hline
\end{tabular}

Fig. 3. Least squares means estimates of offspring leaf length $( \pm \mathrm{SE})$ as a function of treatment and time. See Fig. 1 caption for treatment acronyms.

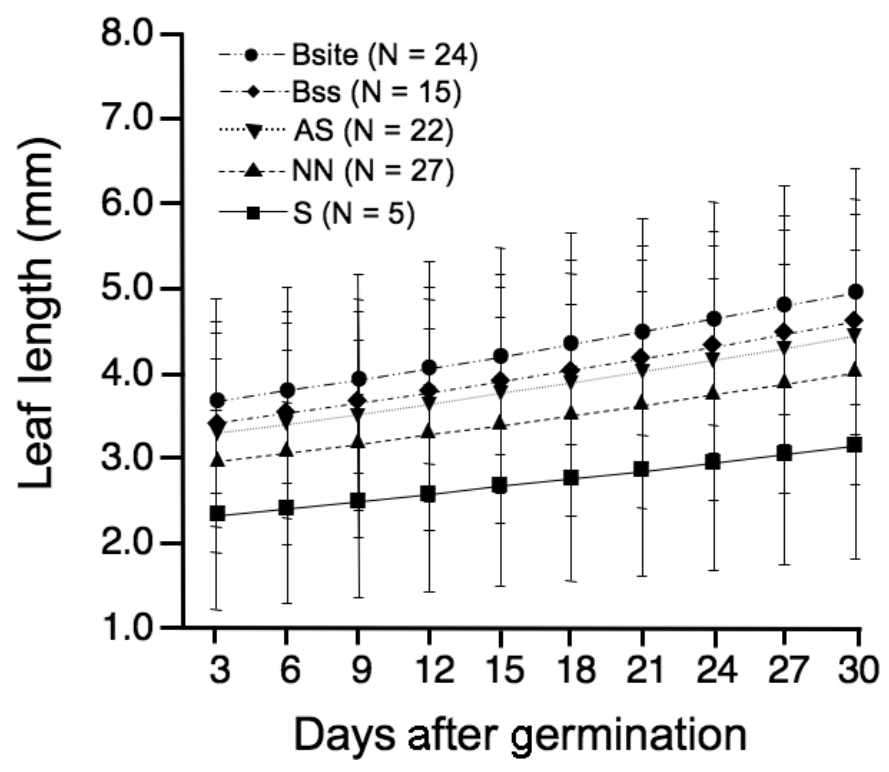

Fig. 4. Estimates of leaf number $( \pm \mathrm{SE})$ as a function of treatment and time. See Fig. 1 caption for treatment acronyms.

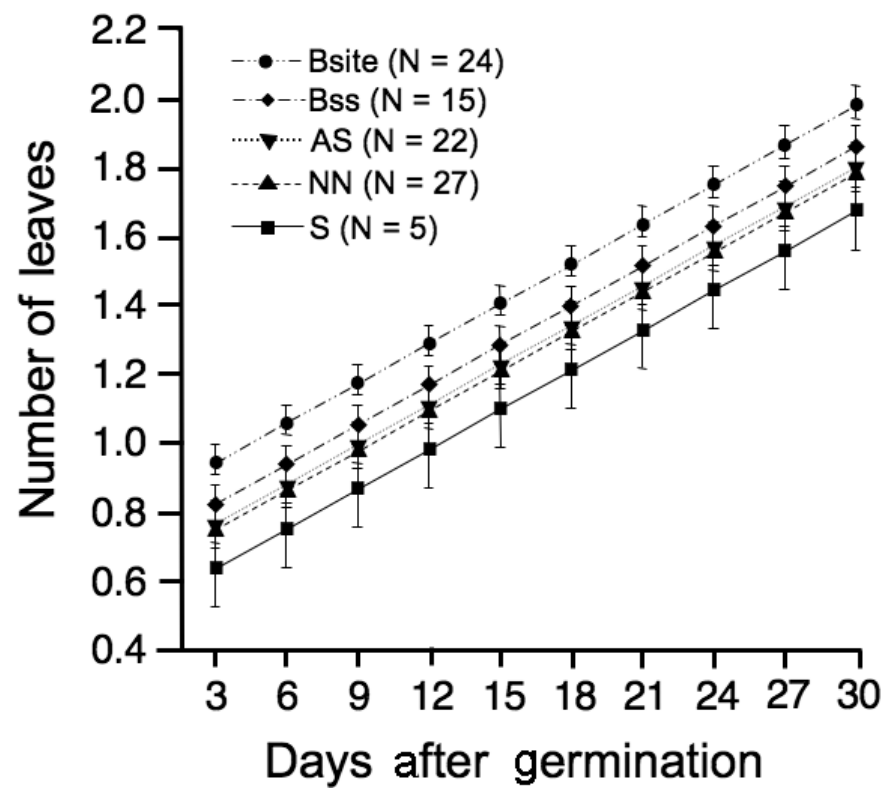

results confirm that L. papilliferum is primarily an outcrossing species. Moreover, our results, combined with those of earlier studies, demonstrate that both small and large L. papilliferum populations share similar spatial structure.

Although the dispersal capacity of pollen and seed has not been measured directly for L. papilliferum, our finding that populations are spatially structured within individual slick spots suggests that both pollen and seed dispersal are low for this species. Consistent with this hypothesis, L. papilliferum fruit and seed lack obvious mechanisms for long-distance dispersal (Moseley 1994), and observations of insect movement on $L$. papilliferum flowers reveal that pollinators often linger on individual plants or within clusters of plants within slick spots (I.C. Robertson, personal observation). Indeed, leptokurtic patterns of pollen movement are typical for insect pollinated plants (Levin and Kerster 1974; Godt and Hamrick 1993).

A population genetics study by Stillman (2006), which included all but one of the $L$. papilliferum populations used in our study, revealed that small populations have significantly less genetic diversity than large populations. This result is consistent with the expectation that small populations experience high levels of inbreeding and reduced genetic variability because of little or no outcrossing with other populations (Ellstrand and Elam 1993). If true for L. papilliferum, one might expect less spatial structure in small populations than in large populations. However, percent fruit set as a function of outcrossing distance did not differ significantly between the 10 small populations and one large population we examined; both categories of population showed clear evidence of spatial structure. Nevertheless, our findings and those of Stillman (2006) are not necessarily contradictory because it is unlikely that the genes represented in Stillman's allozyme analysis are the same ones that affect fruit set. Although small populations of L. papilliferum have less genetic variability than large populations, the consequences of lower genetic variability may not be currently reflected in percent fruit set.

One of the goals of our study was to assess whether L. papilliferum exhibits inbreeding depression. Ideally, for such an assessment, one would include measurements of offspring reproductive success (Waser 1993; Dudash and Fenster 2001). However, few studies of inbreeding depression manage to achieve this goal, and instead rely on surrogate measures of fitness. In our analyses, we considered seed mass, germination rate, and several growth metrics of offspring. Heavier seeds had increased germination success and resulted in larger offspring with longer leaves than offspring originating from lighter seeds. Because photo- 
synthetic capacity often affects fruit set (Niesenbaum 1993; Longer and Oosterhuis 1999; Stewart and Graves 2006), plants with larger and more numerous leaves may produce more offspring than smaller plants with fewer leaves. Indeed, larger L. papilliferum produce more fruit and seed than smaller individuals (Meyer et al. 2005). Thus, enhanced germination and growth resulting from longer outcrossing distances likely have important consequences for individual fitness.

Evidence for inbreeding depression in L. papillferum varied with life stage and growth parameters in developing offspring. Low percent fruit set in the self-pollinated and nearest-neighbor crosses may indicate the occurrence of inbreeding depression, or it may reflect partial self incompatibility that prevents fertilization between closely related individuals. However, increases in offspring leaf length as a function of outcrossing distance suggest inbreeding depression, as does the pattern between outcrossing distance and offspring leaf number, although in the latter case the result was not statistically significant $(P=0.07)$. Neither seed mass nor mean percent seed germination differed significantly as a function of outcrossing distance. However, given the similarity in pattern between percent fruit set and percent germination with respect to outcrossing distance (Figs. 2 and 3, respectively), further investigation is needed to clarify whether inbreeding depression is expressed in germination rates.

Variability in expression of inbreeding depression among characteristics of offspring is not uncommon (Husband and Schemske 1996; Byers 1998; Dudash and Fenster 2001; Galloway et al. 2003). Galloway et al. (2003) found that although inbreeding depression in Campanula americana L. was not expressed in seed set or percent germination, it was expressed in offspring growth and flowering characteristics. Similarly, Silene virginica L. does not exhibit inbreeding depression for percent fruit set or percent seed set, but it does express inbreeding depression for traits that occur later in the life cycle such as leaf number, biomass, and flower production (Dudash and Fenster 2001). Thus, variation in response to inbreeding among individual characteristics highlights the importance of measuring as much of an individual's life cycle as possible when attempting to establish the occurrence of inbreeding depression (Byers 1998). Future studies on L. papilliferum would therefore benefit from consideration of how outcrossing distance effects the capacity of offspring to mature, flower, and produce viable fruit. This information, coupled with our knowledge of how inbreeding affects early growth and development in $L$. papilliferum, will provide a more complete picture of how population structure influences population processes in this rare species.

\section{Acknowledgements}

Financial support was provided by grants from the Idaho Bureau of Land Management, Idaho Army National Guard, and Boise State University. Laura Bond provided invaluable assistance with the statistical analyses. We thank Simon Billinge, Janet Keller, Amy Stillman, and Josh White for assistance in the field and laboratory, and Susan Meyer and Marcelo Serpe for help with seed germination protocols.
Earlier drafts of the manuscript benefited from the comments of James Smith and Peter Koetsier.

\section{References}

Billinge, S.A. 2006. Reproductive performance as a function of outcrossing distance in Lepidium papilliferum (Brassicaceae), a rare plant endemic to southwest Idaho. M.S. thesis, Boise State University, Boise, Idaho.

Burnham, K.P., and Anderson, D.R. 2002. Model selection and multimodel inference: a practical information-theoretic approach. 2nd ed. Springer Science + Business Media, New York, N.Y.

Byers, D.L. 1998. Effect of cross proximity on progeny fitness in a rare and a common species of Eupatorium (Asteraceae). Am. J. Bot. 85: 644-653. doi:10.2307/2446533.

Charlesworth, D., and Charlesworth, B. 1987. Inbreeding depression and its evolutionary consequences. Annu. Rev. Ecol. Syst. 18: 237-268. doi:10.1146/annurev.es.18.110187.001321.

Colket, B. 2005. 2004 habitat integrity and population monitoring of slickspot peppergrass (Lepidium papilliferum). Idaho Department of Fish and Game, Conservation Data Center, Boise, Idaho.

Dudash, M.R., and Fenster, C.B. 2001. The role of breeding system and inbreeding depression in the maintenance of an outcrossing mating strategy in Silene virginica (Caryophyllaceae). Am. J. Bot. 88: 1953-1959. doi:10.2307/3558422.

Ellstrand, N.C., and Elam, D.R. 1993. Population genetic consequences of small population size: implications for plant conservation. Annu. Rev. Ecol. Syst. 24: 217-242. doi:10.1146/ annurev.es.24.110193.001245.

Galloway, L.F., Etterson, J.R., and Hamrick, J.L. 2003. Outcrossing rate and inbreeding depression in the herbaceous autotetraploid, Campanula americana. Heredity, 90: 308-315. doi:10.1038/sj. hdy.6800242. PMID:12692584.

Godt, M.J.W., and Hamrick, J.L. 1993. Patterns and levels of pollen-mediated gene flow in Lathyrus latifolius. Evolution, 47: 98-110. doi:10.2307/2410121.

Husband, B.C., and Schemske, D.W. 1996. Evolution of the magnitude and timing of inbreeding depression in plants. Evolution, 50: 54-70. doi:10.2307/2410780.

Lande, R. 1995. Mutation and conservation. Conserv. Biol. 9: 782791. doi:10.1046/j.1523-1739.1995.09040782.x.

Levin, D.A. 1984. Inbreeding depression and proximity-dependent crossing success in Phlox drummondii. Evolution, 38: 116-127. doi:10.2307/2408551.

Levin, D.A., and Kerster, H.W. 1974. Gene flow in seed plants. Evol. Biol. 7: 139-220.

Longer, D.E., and Oosterhuis, D.M. 1999. Cotton regrowth and recovery from early season leaf loss. Environ. Exp. Bot. 41: 67-73. doi:10.1016/S0098-8472(98)00050-1.

Meyer, S.E., Quinney, D., and Weaver, J. 2005. A life history study of the Snake River plains endemic Lepidium papilliferum (Brassicaceae). West. N. Am. Nat. 65: 11-23.

Milliken, G.A., and Johnson, D.E. 1992. Analysis of messy data. Vol. 1. Designed experiments. Chapman and Hall, New York, N.Y.

Moseley, R.K. 1994. Report on the conservation status of Lepidium papilliferum. Idaho Department of Fish and Game, Conservation Data Center, Boise, Idaho.

Niesenbaum, R.A. 1993. Light or pollen — seasonal limitations on female reproductive success in the understory shrub Lindera benzoin. J. Ecol. 81: 315-323. doi:10.2307/2261501.

Oostermeijer, J.G.B., Altenburg, R.G.M., and den Nijs, H.C.M. 1995. Effects of outcrossing distance and selfing on fitness com- 
ponents in the rare Gentiana pneumonanthe (Gentianaceae). Acta Bot. Neerl. 44: 257-268.

Quinney, D. 1998. LEPA (Lepidium papilliferum). Report on file at: State of Idaho, Military Division, Idaho Army National Guard, Boise, Idaho.

Robertson, I.C. 2004. Importance of outcrossing for fruit production in slickspot peppergrass, Lepidium papilliferum L. (Brassicaceae). West. N. Am. Nat. 64: 265-268.

Robertson, I.C., and Klemash, D. 2003. Insect-mediated pollination in slickspot peppergrass, Lepidium papilliferum L. (Brassicaceae), and its implications for population viability. West. N. Am. Nat. 63: 333-342.

Robertson, I.C., and Ulappa, A.C. 2004. Distance between pollen donor and recipient influences fruiting success in slickspot peppergrass, Lepidium papilliferum. Can. J. Bot. 82: 1705-1710. doi:10.1139/b04-138.

SAS Institute Inc. 2003. SAS/STAT user's guide. Version 9. SAS Institute Inc. Cary, N.C.

Sobrevila, C. 1988. Effects of distance between pollen donor and pollen recipient on fitness components in Espeletia schultzii. Am. J. Bot. 75: 701-724. doi:10.2307/2444203.
Stewart, J.R., and Graves, W.R. 2006. Photosynthesis, growth, carbon allocations, and fruit load of Frangula caroliniana and Rhamnus cathartica. Int. J. Plant Sci. 167: 1161-1168. doi:10. 1086/507650.

Stillman, A.J. 2006. Population genetics and mating system of the rare polyploid Lepidium papilliferum (Brassicaceae), a southwestern Idaho endemic. M.S. thesis, Boise State University, Boise, Idaho.

Waser, N.M. 1993. Population structure, optimal outbreeding, and assortative mating in angiosperms. In The natural history of inbreeding and outbreeding: theoretical and empirical perspectives. Edited by N.W. Thornhill. University of Chicago Press, Chicago, Ill. pp. 173-199.

Waser, N.M., and Price, M.V. 1989. Optimal outcrossing in Ipomopsis aggregata: seed set and offspring fitness. Evolution, 43: 1097-1109. doi:10.2307/2409589.

Waser, N.M., and Price, M.V. 1994. Crossing distance effects in Delphinium nelsonii: outbreeding depression and inbreeding depression in progeny fitness. Evolution, 48: 842-852. doi:10. $2307 / 2410491$. 